\title{
Monitoring The Learning Process at SMK Kesatrian Through Kana Buso Application
}

\author{
Monitoring Proses Pembelajaran Di SMK Kesatrian Melalui Kana Buso Application
}

Received:

17 December 2019

Accepted:

22 June 2020

Published:

19 August 2020

\author{
1*Tyas Pratama Puja Kusuma, ${ }^{2}$ Muhamad Awiet Wiedanto \\ Prasetyo \\ ${ }^{1,2,}$ Sistem Informasi, Universitas Amikom Purwokerto \\ 1,2 Purwokerto, Indonesia \\ E-mail: ${ }^{1}$ tyaspratama@amikompurwokerto.ac.id, \\ ${ }^{2}$ mawp@amikompurwokerto.ac.id
}

*Corresponding Author

\begin{abstract}
The research aims to produce applications that can analyze the quality of the questions, know the statistics of student grades, and determine the appropriateness of the items to be tested for the subjects of network system administration competence in Computer Network Engineering Class XI Vocational School Kesatrian. Research and development. The development model in this study uses the Analysis-Design-Development-Implementation-Evaluation (ADDIE) Model. With the stages of development, ranging from analysis, planning, development, implementation, and evaluation. The application is developed based on the website. This research resulted in the form of question items named Kana Buso Application, which is suitable as a medium for determining the quality of questions. This application is useful to make it easier for teachers to assess the quality of the items that will be given to students. Based on the test results, it can be concluded that the use of this application can also minimize student cheating in working on exam questions because the questions issued are random.
\end{abstract}

Keyword-Learning Outcomes, ADDIE Model, Kana Buso Application

Abstrak-Penelitian ini untuk menghasilkan aplikasi yang dapat menganalisis kualitas soal, mengetahui statistik nilai siswa, mengetahui kelayakan soal yang akan diujikan untuk mata pelajaran administrasi sistem jaringan kompetensi keahlian Teknik Komputer Jaringan Kelas XI SMK Kesatrian. Metode penelitian yang digunakan adalah research and development. Model pengembangan dalam penelitian ini menggunakan model Analysis-Design-Development-Implementation-Evaluation (ADDIE). Dengan tahapan pengembangannya mulai dari analisis, perencanaan, pengembangan, implementasi dan evaluasi. Aplikasi yang dikembangkan berbasis website. Penelitian ini menghasilkan aplikasi butir soal yang diberi nama Kana Buso Application yang layak sebagai media penentu kualitas soal. Aplikasi ini bermanfaat untuk mempermudah guru menentukan kualitas soal yang akan diberikan kepada siswa. Dapat disimpulkan rata-rata hasl pengujian sebesar 93\% dan penggunaan aplikasi ini juga dapat meminimalisir kecurangan siswa dalam mengerjakan soal ujian karena soal yang dikeluarkan bersifat random.

Kata Kunci-Hasil Belajar, Model ADDIE, Kana Buso Application

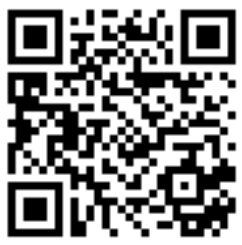


INTENSIF, Vol.4 No.2 August 2020

ISSN: 2580-409X (Print) / 2549-6824 (Online)

DOI: https://doi.org/10.29407/intensif.v4i2.14000

\section{INTRODUCTION}

Education has an essential role in the process of increasing human resources. However, education is currently in the spotlight in terms of curriculum changes. Changes in the education system due to a lack of information about educational outcomes, practices, programs, and the lack of a standard method for obtaining such information. Achieve educational success by assessing the results of education itself.

Educational assessment by collecting and processing information to be measured or assessed its achievement in the form of student learning outcomes. Variables that get an evaluation include authentic assessment, self-assessment, portfolio-based assessment, daily test results, competency level tests, quality competency level tests, midterm or end semester tests, national exams, and school exams [1]. One way to evaluate education is by evaluating instruments such as skills in non-academic fields and academics by working on an essay and multiple-choice questions.

MCQs are done as an objective measurement tool that is presented with short answers. There is one answer that is most appropriate and very effective because MCQs can test various material topics in a test, compared to essay tests that require long solutions [2]. While the limitations are that it takes a long time to write questions, determine the most appropriate answers, the difficulty of giving homogeneous answers, there is an opportunity to guess the answer key [3]. A form of exam that can inform achievement between students or between schools and even between regions requires an excellent standardized test. So, it takes qualified teachers who can write test questions and the willingness to develop their abilities in making test questions.

At present, it is realized that the evaluation is based on the Education Unit Level Curriculum, which is still mostly used by schools (in grades XI and XII). The evaluation process is carried out to know the extent to which learning objectives have been achieved. Also, evaluation can be used as a tool to do what actions will be taken next. Therefore, evaluation plays an essential role in providing results that can be carried out in ongoing or has taken place. Measuring achievement of learning outcomes can involve quantitative measurements that produce quantitative data, such as tests and scores[4]. One of the writing items mastered by the teacher is writing choice items. One of the evaluation tools used by the teacher is a test [5], while the test is "An instrument or systematic procedure for measuring a sample of behavior" (the test is a systematic instrument or procedure for measuring a sample of behavior) [6].

The choice test is seen from the criteria of answering by choosing alternative answers. An objective analysis is a test obtained based on an accurate assessment method without the subjective element of the assessor. It is possible because there is an answer key as a binding guideline. With the answer key, whoever evaluates it, whatever the votes, will be the same. 
Multiple-choice tests have long been used as evaluation tools by teachers. Until now, there has been no accurate information about the suitability of the grid, the rules for the preparation of questions, and the Indonesian language in the multiple-choice questions. For this reason, researchers are interested in researching to find information about the suitability of the grid, the rules of preparing questions, and the Indonesian language on multiple-choice items.

Based on the preliminary observations at SMK Kesatrian Purwokerto by asking for softcopy of questions on the curriculum, the researcher found several errors in terms of the rules of writing questions and the Indonesian language in Indonesian subjects. Based on these problems, research is needed to help teachers write multiple-choice items according to existing theories in terms of the preparation of the grid, the rules of writing questions. The Indonesian language rules [7].it can be achieved by analyzing the issues to find mistakes made by the teacher in writing multiplechoice items. Research describes the analysis of students' daily test tests (formative) in terms of the substance of the test items analyzed in terms of language and language skills. In contrast, communicative competence elements are analyzed from grammar, sociolinguistics, discourse, and strategy [8].

This study's results indicate that the quality of formative tests follows the communicative approach based on authentic assessment and meets the elements of communicative competence (grammatical, sociolinguistic, discourse, and strategy). Research that has been done to determine the validation of exam questions, reliability of exam questions, level of difficulty of exam questions, differentiation of exam questions, and the effectiveness of exam questions distractors shows results that are still in the category of being made in exam questions [9]. Utilization of information technology in the form of the internet-connected to a service provider computer or often referred to as a server and client computer installed with web server software, databases, and internet services, can maximize the process of learning outcomes.

The absence of processing and structuring in carrying out computer-based exams makes most teachers in schools reluctant to implement reviews with computers. Therefore the idea arises of developing an online exam with easy use; both teachers and students can increase the effectiveness and efficiency of time in the examination and implementation process so that the review will be easy to implement, exciting, and enjoyable for students [10]. Research that has a high school subject at Prambanan 1 already utilizes information technology. These are the use of Google Form, producing more effectively compared to conventional media such as paper and is more efficient in terms of cost, time, and energy. As a whole, it is worth using as a medium to find out student learning outcomes [11].

A variety of studies create item analysis applications but have not been effective because they use foreign languages that are less familiar and make it difficult to understand their use. Also, the 
INTENSIF, Vol.4 No.2 August 2020

ISSN: 2580-409X (Print) / 2549-6824 (Online)

DOI: https://doi.org/10.29407/intensif.v4i2.14000

information provided displays in various formats, making it difficult for users to understand the application. Existing research by assisting teachers in assessment activities and developing practical and applicative item analysis applications results in a slight role in the teacher's need to analyze items in the class [12]. Then research from the Faculty of Psychology, Airlangga University, published an evaluation form for the online exam for multiple-choice questions. The advantage is that students can see the test scores directly, item analysis can be done directly, testers do not need to make corrections manually mapping scanning and randomization of questions and answer options make it difficult for students to cooperate in completing the test so that cheating behavior can be avoided [13]. With the problem and which is supported by research references that have been done before, the researcher has the aim to produce an information system to monitor the learning outcomes of students of Kesatrian Vocational School through the Kana Buso Application.

\section{RESEARCH METHOD}

Research and Development (Research and Development) is used to produce specific products and test their effectiveness [14]. Research and Development (R) emphasizes useful products in various forms: extensions, additions, and innovations from existing structures. This research will develop a product in the way of application analysis items on Network System Administration subjects to determine the quality of questions in SMK Kesatrian. This development research adapted the Analysis-Design-Development-Implementation-Evaluation (ADDIE) model [15]. The level of design of learning and development material, systematics as a procedural aspect of the systems approach has been realized in many methodological practices for the design and construction of texts, audiovisual materials, and computer-based learning materials [16]. The selection is based on the consideration that this model is developed systematically and rests on the theoretical foundation of learning design. Figure 1 is the framework of the research thinking: 


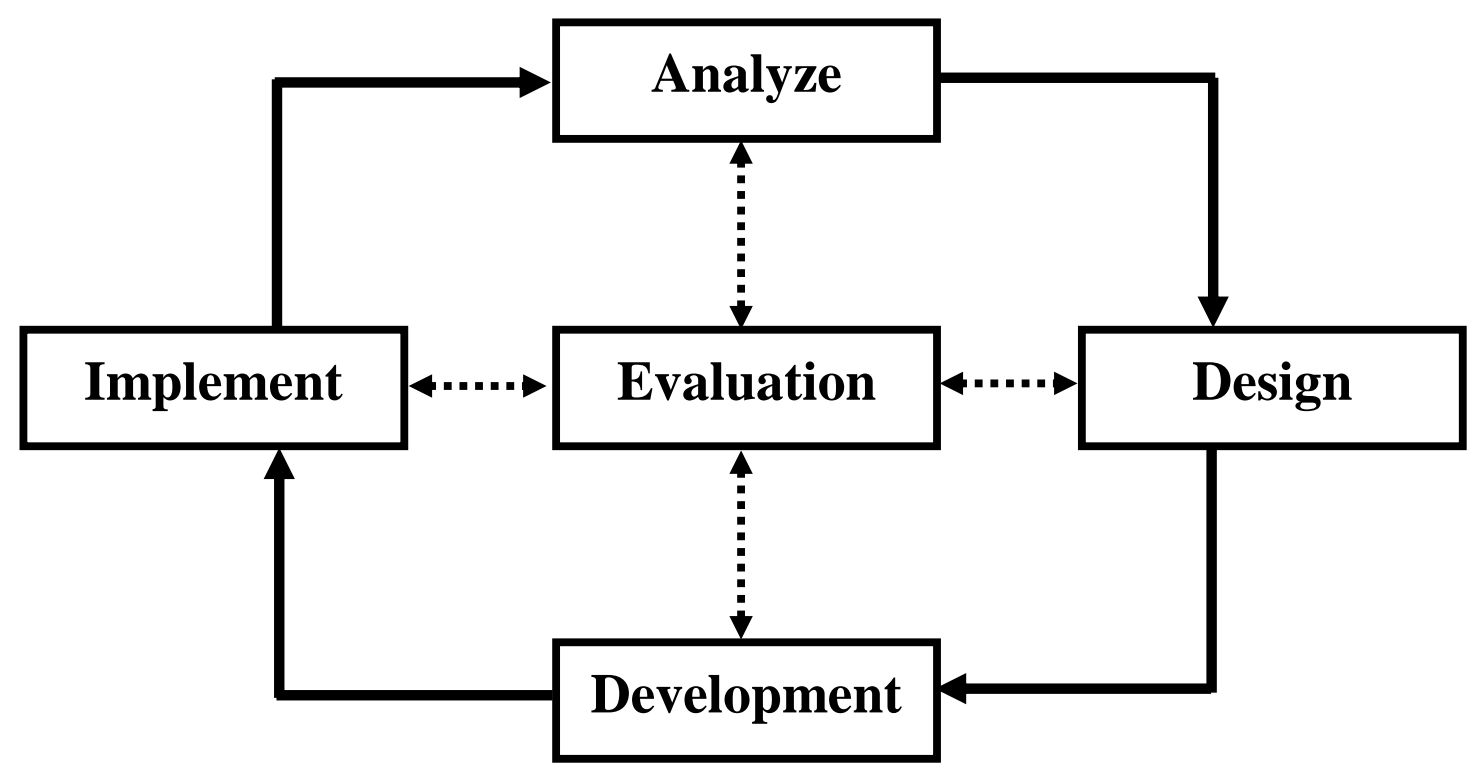

Figure 1. ADDIE METHOD

Data collection techniques used were interviews (two-way interview) is a two-way communication to get data from correspondents [17]. Discussions in this study were conducted with SMK Kesatrian Purwokerto teachers to obtain information directly about the research. Observation The observation method is a method of collecting data by observing and systematically recording the investigated [18]. Inspections are carried out according to specific procedures and rules so that researchers can repeat them, and the results of observations provide the possibility to be interpreted scientifically. In this study, comments were made at SMK Kesatrian Purwokerto. Documentation is a qualitative data collection method with several facts and data stored in the material in the form of literature [19]. Some data are in the form of letters, diaries, photo archives, meeting results, activity journals, etc. This documentary material is divided into several types, namely autobiography, personal letters, books or diaries, memorials, clippings, government documents, or private data on servers and flash disks, data stored on websites, and others. This research document is to collect information related to research needs obtained from websites and books. Measurement in education includes measuring the ability of test-takers and measuring the characteristics of the measuring instruments used. Two measurement theories are still developing, namely classical test theory and modern test theory. Determination of the quality of the questions in this study using classical test theory. 
INTENSIF, Vol.4 No.2 August 2020

ISSN: 2580-409X (Print) / 2549-6824 (Online)

DOI: https://doi.org/10.29407/intensif.v4i2.14000

\section{RESULT AND DISCUSSION}

\section{A. Observation and Interview}

Field study is an initial research activity carried out to determine and understand the school's condition, a description of the system, and some of the problems that occur at the school. The methods used in this field study include observation, which is direct observation of the school, which is carried out to determine the process of teaching and learning, computer specifications, how many computers are available, and how much internet bandwidth is available. Allocated for computer labs. Next to the interview is data and information collection techniques by asking questions directly with the school about the KBM process, such as lab use schedules, courses that require labs, lab use, and school Wi-Fi procedures

\section{B. Formulation and Research Objectives}

Based on the observation and interview data collection, the researcher provides a solution that has been adapted to the needs of the field, namely producing item analysis applications so that later it will be easier for teachers to give questions to students. The data obtained for evaluating the issues for each subject are then used as a guide for preparing evaluation materials that will be contained in the development product. Development is the process of turning a blueprint into reality. At this stage, a web-based item evaluation application was developed. Implementation is a concrete step to implement the developed system. That is, at this stage, all that has been designed is installed or set in such a way as to be appropriate for its role or function to be implemented. The implementation phase of this research was carried out by testing the application directly. This menu can be accessed by typing / entering the URL http://analsoal.com/ in the browser. A website admin can only access the Admin page.

\section{Systems Development Method}

This page requires the correct NIK and PIN to access the administrator page. There are eight menus on the administrator page, and three of them are menus that are not on the teacher page due to different levels of access. The list is the teacher's menu, the subject menu and submenus, add, edit, and delete students. To add a new teacher, click the "Add Teacher" button, and the added teacher page will appear, as shown in Figure 2. Administrator page 
INTENSIF, Vol.4 No.2 August 2020

ISSN: 2580-409X (Print) / 2549-6824 (Online)

DOI: https://doi.org/10.29407/intensif.v4i2.14000

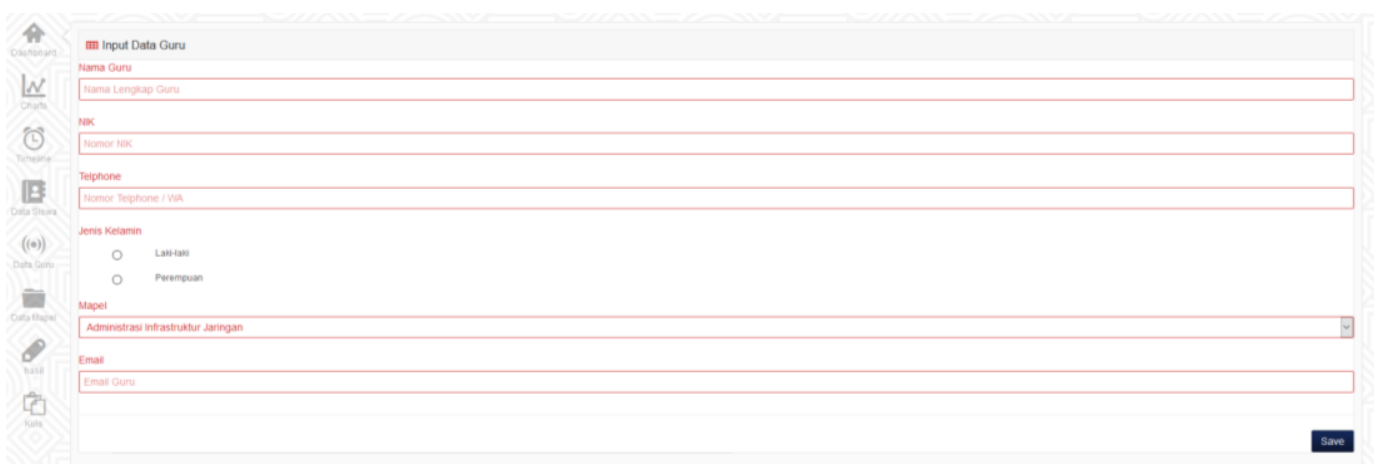

Figure 2. ADMINISTRATOR PAGE

Based on Figure 3. Adding Students is used to enter students' identities at the same time used as access rights when working on the questions given by the teachers based on the subjects to be implemented.

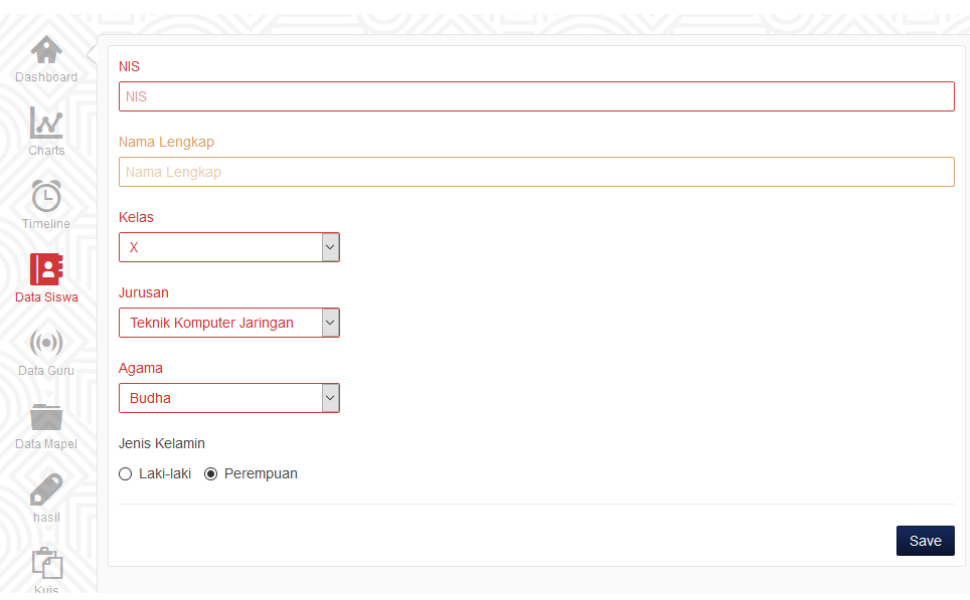

Figure 3. ADD STUDENTS

While Figure 4. Question List and Answer Key, a list of questions and answer key menu will appear after the teachers have inputted the data and answer key for each subject.

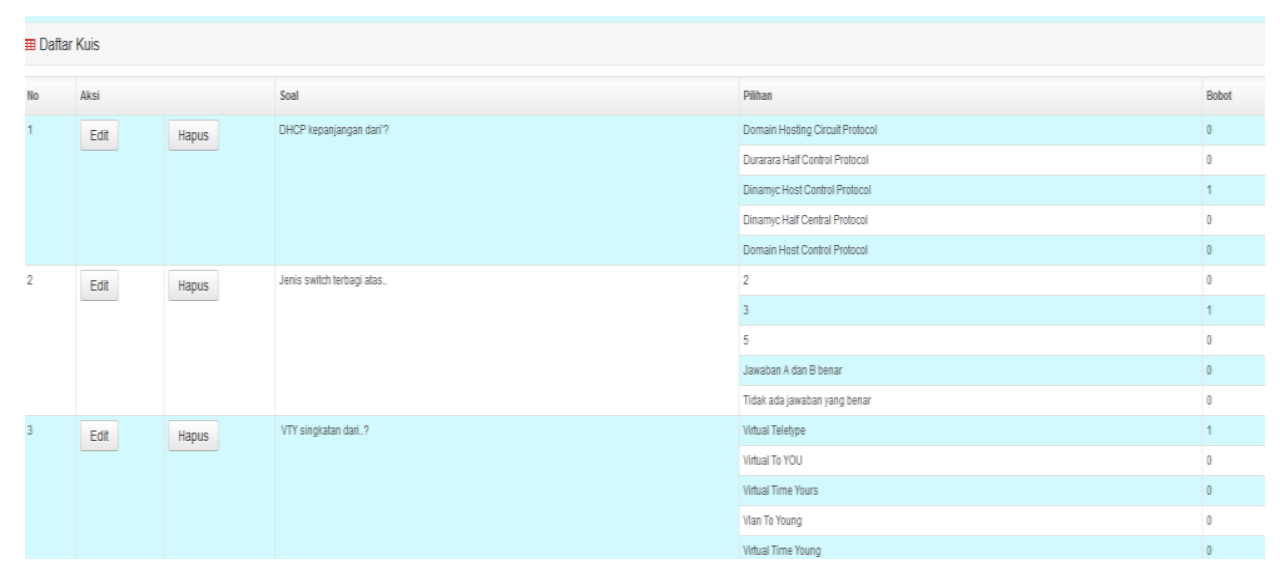

Figure 4. QUESTION LIST AND ANSWER KEY 
INTENSIF, Vol.4 No.2 August 2020

ISSN: 2580-409X (Print) / 2549-6824 (Online)

DOI: https://doi.org/10.29407/intensif.v4i2.14000

After students log in, students will be given multiple-choice questions. This menu displays the student's name, register number, time to work on, and countdown or countdown in working on the problem. Intentional questions are not given the $\mathrm{ABCDE}$ option because the multiple-choice random order format between one student and another can minimize cheating and prevent leakage of answer keys like Figure 5. Spelling Information and Test Questions.

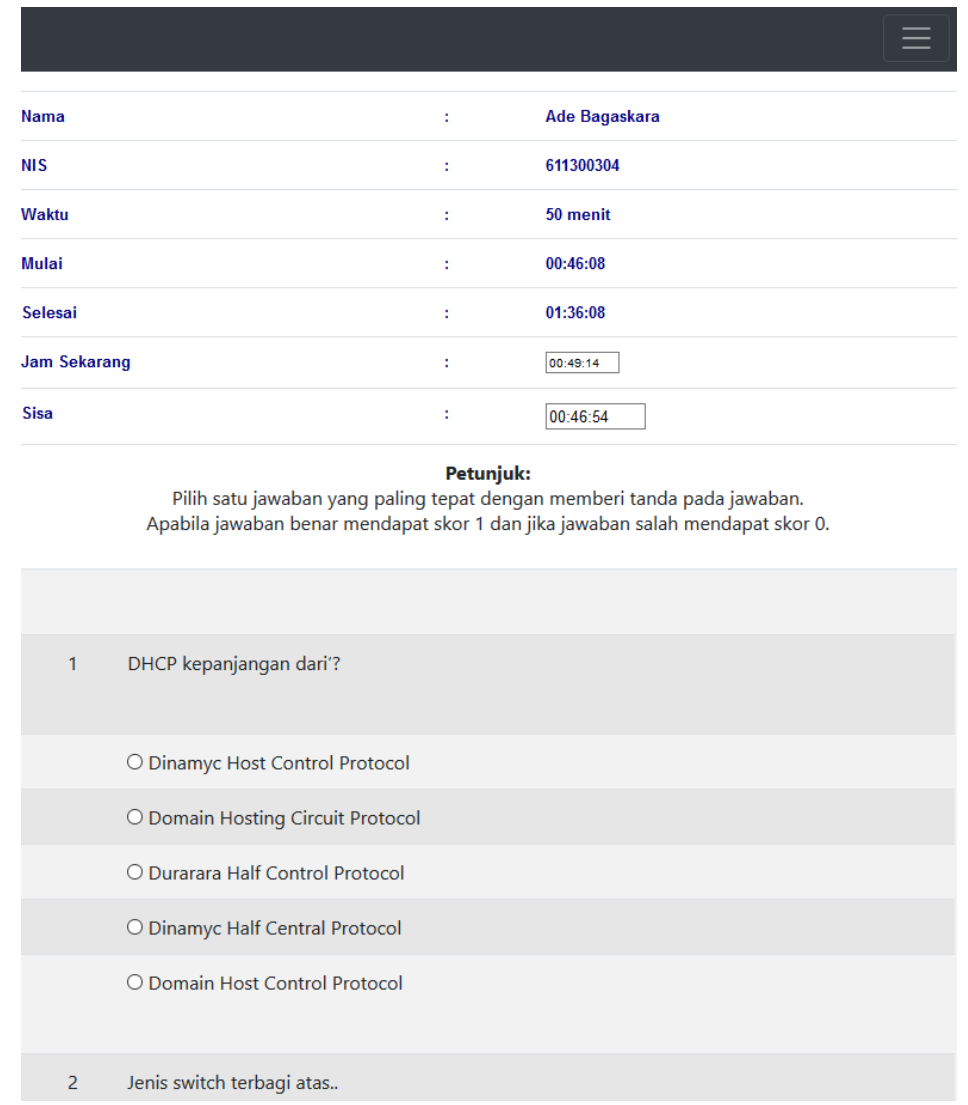

Figure 5. SPELLING INFORMATION AND TEST QUESTIONS

\section{Application Testing}

Respondents tested the application by taking data from three classes. The data obtained by $70 \%$ of students assessing the app has an attractive appearance, easy to understand, and willing to use the app for learning activities, while $12 \%$ of them are still evaluating confused utilizing the application and the remaining $18 \%$ assess the app, it's quite reasonable. 


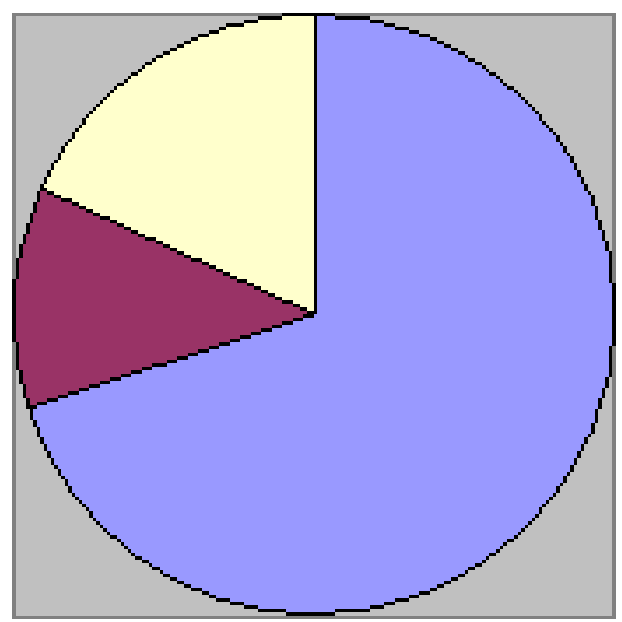

\section{$\square$ YA \\ 口TIDAK \\ 口BIASA SAJA}

Figure 6. INTERFACE ASSESSMENT

Based on Figure 7. Assessment of Application Usage, explains that the evaluation for aspects of registration features, opening applications, accessing the material, and taking tests from all three classes has an average of 93\%. The lowest rating is in the test feature obtained from TKJ 1 class with a value of $82 \%$, and the highest score in the element opens the application and accessing material with an amount of $100 \%$ in TKJ 3 class.

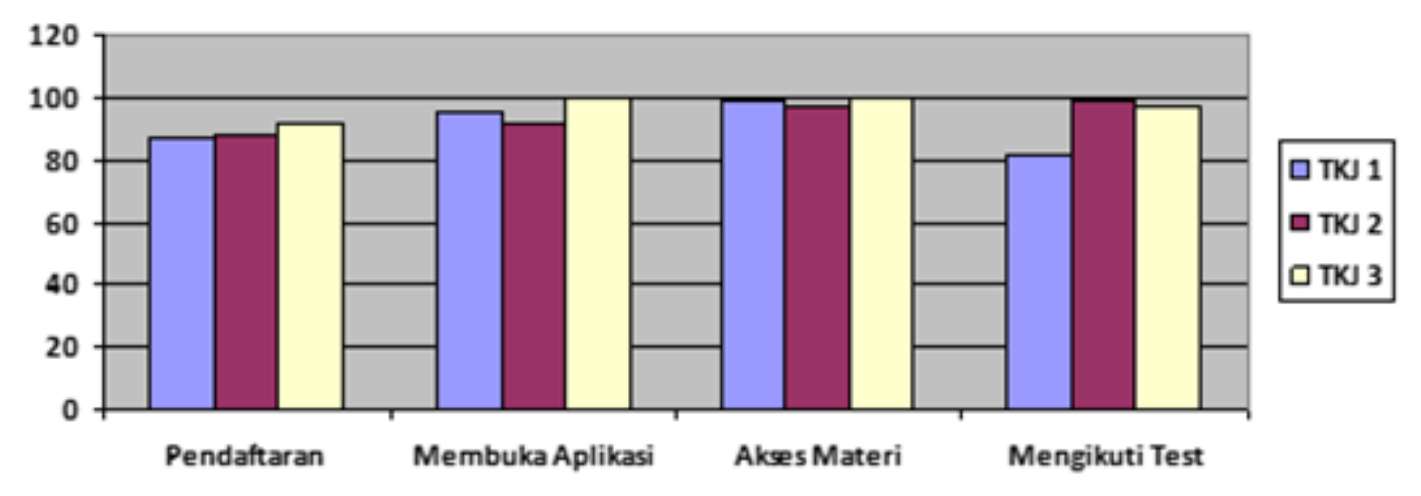

Figure 7. APPLICATION USAGE ASSESSMENT 


\section{CONCLUSION}

Based on research conducted at SMK Kesatrian Purwokerto, it can be concluded that a website-based online exam application has been successfully developed as a medium for student learning evaluation. While the test results can be drawn, conclusions get an average of $93 \%$. This online exam application can be accessed by entering the URL http://anal-soal.com/ in the browser. Suggestions from researchers in conducting online examinations should use a personal computer with stable internet access. Some additional facilities can be added to this application without eliminating the basic needs - the need for the testing of an online system testing application security. As for the advice in the implementation of online examinations, you should use a personal computer with stable internet access. Additional facilities can be added without eliminating the requirements and the need for security of online testing system testing applications.

\section{ACKNOWLEDGMENTS}

Thank you to the Directorate General of Research and Technology Strengthening the Ministry of Research, Technology, and Higher Education for funding this research. The Institute of Research and Community Service at the University of Amikom Purwokerto has facilitated study during the process. Then all parties who could not be mentioned one by one, to support the course of this research.

\section{REFERENCES}

[1] U. Salamah, "Penjaminan Mutu Penilaian Pendidikan," Evaluasi, J. Manaj. Pendidik. Islam, vol. 2, 2018.

[2] I. N. S. S. Ni Putu Sintya Winata, Ida Bagus Putrayasa, "Analisis Butir Soal Pilihan Ganda Mata Pelajaran Bahasa Indonesia SMK Negeri 3 Singaraja," J. Pendidik. dan Sastra Indonesia., vol. 2 No.1, 2014.

[3] Y. E. Suryani, "Pemetaan Kualitas Empirik Soal Ujian Akhir Semester Pada Mata Pelajaran Bahasa Indoensia SMA di KAbupaten Klaten," J. Penelitian dan Evaluasi Pendidikan., vol. 21 No.2, 2017

[4] N. R. Mujib., A. J. E. Toenlio., dan H. Praherdhiono., "Analisis Butir Soal Ujian Nasional IPA SD/MI Tahun 2015 Sampai 2017 Berdasarkan Taksonomi Bloom,” J. Kajian Teknologi Pendidikan., vol. 1 No.2, 2018.

[5] Herwelis, "Analisis Kualitas Soal Ujian Akhir Sekolah (UAS) Mata Pelajaran Matematika Tingkat SMK Kabupaten Takalar Tahun Pelajaran 2012/2013," Universitas Negeri Makassar, 2013.

[6] E. T. Wahyuningsih, "Analisis Butir Soal Tes Objektif Buatan Guru Ulangan Semester Ganjil Mata Pelajaran Ekonomi Kelas X Di SMA Negeri 1 Mlati Tahun Ajaran 2013/2014," Universitas Negeri Yogyakarta, 2015. 
[7] R. Kurniawati dan Irsyadillah., "Analisis Nilai Karakter Dalam Teks Cerita Buku Pelajaran Siswa Sekolah Dasar,” J. Master Bahasa., vol. 6 No.2, 2018.

[8] E. Astriani, "Kompetensi Komunikatif," PENTAS J. Ilm. Pendidik. Bhs. dan Sastra Indones., vol. 2, 2018.

[9] Pasi., Srika Ningsih dan Yusrizal., "Analisis Butir Soal Ujian Bahasa Indonesia Buatan Guru MTsN di Kabupaten Aceh Besar," Ilm. Pendidik. Bhs. dan Sastra Indonesia., vol. 6, 2018.

[10] L. Satria., Devit dan Wati., "Perancangan Ujian Online Menggunakan Model Computer Based Assessment Berbasis Client-Server (Studi Kasus: SMA PGRI Kota Payakumbuh)," Invotek Polbeng - Seri Inform., vol. 1, 2016.

[11] A. N. P. N. Dwi Purwati., dan., "Pengembangan Media Evaluasi Pembelajaran Sejarah Berbasis Google Formulir Di SMA N 1 Prambanan," Pendidik. dan Sej., vol. 14, 2018.

[12] K. Muhson, Ali,. Lestari, Barkah,. Supriyanto., \&, Baroroh, "Pengembangan Software AnBuso sebagai Solusi Alternatif bagi Guru dalam Melakukan Analisis Butir Soal Secara Praktis dan Aplikatif," Yogyakarta, 2013.

[13] E. Mastuti, "Pemanfaatan Teknologi Dalam Menyusun Evaluasi Hasil Belajar," Penelit. Psikol., vol. 7, 2016.

[14] Hanafi, "Konsep Penelitian R\&D Dalam Bidang Pendidikan," Kaji. Kesilaman, vol. 4, 2017.

[15] R. H. S. Rindang Wijayanto., dan., "Pengembangan Bahan Ajar Matematika Dengan Pendekatan Problem Solving Berorientasi Pada Kemampuan Pemecahan Masalah," Pendidik. Mat., vol. 7, 2018.

[16] I. M. K. I Made Tegeh., dan., "Pengembangan Bahan Ajar Metode Penelitian Pendidikan Dengan ADDIE Model," J. Ika, vol. 11, 2013.

[17] A. I. Mubarok, "Pelaksanaan Komunikasi Organisasi Di Dinas Pendidikan Kabupaten Klaten," E-Prints Univ. Negeri Yogyakarta, 2016.

[18] Falimu, "Etika Komunikasi Pegawai Terhadap Pelayanan Penerbitan Pajak Bumi dan Bangunan," Komunikator, vol. 9, 2017.

[19] S. Bakhri, "Animasi Interaktif Pembelajaran Huruf dan ANgka Menggunakan Model ADDIE,” J. Intensif, vol. 3 No. 2, 2019.

[20] B. I. Suwandayani, "Analsis Perencanaan Pembelajaran Tematik Pada Kurikulum 2013 Di SD Negeri Kauman 1 Malang,” Elem. Sch. Educ. J., vol. 2, 2018. 